\title{
Sex Discrimination and the Fourteenth Amendment: Lost History
}

\author{
Nina Morais
}

I tink dat 'twixt de niggers of de Souf and de womin at de Norf, all talkin' 'bout rights, de white man will be in a fix pretty soon. -Sojourner Truth, $1851^{1}$

Courts and legal scholars agree that the Fourteenth Amendment should be used to determine the legality of state actions that discriminate on the basis of sex. ${ }^{2}$ This consensus rests on the Fourteenth Amendment's broad language, ${ }^{3}$ not on the intent of its framers: Most people believe that the framers had an overriding interest in prohibiting racial discrimination, but virtually no awareness that the Amendment might be applied to sex discrimination. This Note questions the accuracy of this consensus view by

1. The Concise History of Women's Suffrage 6 (M. Buhle \& P. Buhle eds. 1978) thereinafter CHWS].

2. See G. Gunther, Constitutional Law 642-44 (11th ed. 1985) and cases cited therein. Exceptions to the consensus on the Fourteenth Amendment are increasingly rare. See Judge Bork vs. Himself: Evolution of His Views, N.Y. Times, Sept. 21, 1987, at B14, col. 4, quoting Supreme Court nominee Judge Robert Bork's June 1987 "Worldnet" broadcast ("I do think that the equal protection clause probably should have been kept to things like race and ethnicity. When the Supreme Court decided that having different drinking ages for young men and young women violated the equal protection clause, I thought that . . . was to trivialize the Constitution and to spread it to areas it did not address."); Bork, Neutral Principles and Some First Amendment Problems, 47 IND. L.J. 1, 11 (1971) (equal protection clause requires formal procedural equality and bars racial discrimination-nothing nore); Trimble v. Gordon, 430 U.S. 762 (1977) (Rehnquist, J., dissenting) (Supreme Court's equal protection decisions are unsupported except in area of law where framers meant clause to apply: classifications based on race or national origin); Strauder v. West Virginia, 100 U.S. (10 Otto) 303, 310 (1879) (purpose of Fourteenth Amendment was to prohibit race discrimination; women but not blacks can be excluded from juries); Slaughter-House Cases, 83 U.S. (16 Wall.) 36, 71 (1872) ("pervading purpose" of Fourteenth Amendment was to protect newly freed slaves).

3. See J. BaER, EQUality under the Constitution: Reclaiming the Fourteenth AMENDMENT 92 (1983) (language of Fourteenth Amendment supports inclusion of women and children); Bickel, The Original Understanding and the Segregation Decision, 69 HARv. L. REv. 1, 60 (1955) (framers' decision to use general language not tied to race was conscious); see also SlaughterHouse Cases, 83 U.S. (16 Wall.) 36, 89 (1873) (Bradley, J., dissenting) (blacks are not only beneficiaries of Amendment since language is deliberately general); id. at 128-29 (Swayne, J., dissenting) (Amendment's language includes all persons; Court cannot interpolate limitation to racial claims neither expressed nor implied). Only one scholar, John Hart Ely, has argued that the framers deliberately intended the Fourteenth Amendment to reach discrimination not based on race. But the historical evidence he offered was too slim to support his argument. See J. ELY, DEMOCRACY and DisTRUST 23-24 (1980).

4. See, e.g., J. BAER, supra note 3, at 89 (1983) (in congressional debates on Fourteenth Amendment, there was "some agreement that it did not cover women"); Maltz, Some New Thoughts on an Old Problem-The Role of the Intent of the Framers in Constitutional Theory, 63 B.U.L. REv. 811, 
exploring the Fourteenth Amendment's historical context and early interpretation. The Note concludes that this clear-cut image of intent is belied by a more complicated history.

Section I shows that during the debates over the Amendment, the framers were vigorously lobbied by the nation's leading suffragists, who petitioned Congress to protest the use of the word "male" in the section of the Amendment that deals with voting. The suffragists' petitions kept the framers keenly aware of the battle for women's enfranchisement, and the battle for women's rights in general. This version of the Fourteenth Amendment's history differs from the usual image of the framers as so preoccupied with racial discrimination that they were unaware of the demands of other politically disadvantaged groups.

Section I argues further that any attempt to understand the framers' intent must take into account their awareness of women's political concerns. To the extent that the framers were familiar with the progressive political culture of their day, they might easily have guessed that reformers would press courts with the claim that the Fourteenth Amendment was applicable to women as well as to blacks. In this historical context, it is implausible that the framers wished the Amendment to apply only to blacks, but never said so explicitly.

Section II describes the early interpretation of the Fourteenth Amendment. In the 1870's, suffragists petitioned Congress to use the Amendment to prevent the states from disfranchising women. Congress did not agree that the Amendment guaranteed women the right to vote, but it did agree that this question of sex discrimination should be decided under the Amendment. In addition, nineteenth- and early twentieth-century courts almost unanimously reached the same conclusion that Congress did in the 1870's: Sex discrimination cases may be decided under the Fourteenth Amendment.

This Note argues that there is more than one plausible reading of the Fourteenth Amendment's history. Legal arguments based on original intent are persuasive only to the extent that the historical evidence is unequivocal. If the history supports several interpretations, as it does here, original intent should be much less important. The current interpretation of the Fourteenth Amendment in sex discrimination cases-specifically, the intermediate level of scrutiny used in these cases-is in part based on scholars' certainty that the framers never intended the Amendment to reach sex discrimination. ${ }^{5}$ The history detailed below at least undermines

813 (1983) ("[T]here is no evidence that the [Fourteenth Amendment's] Framers intended to prohibit state-imposed sex discrimination. . . ."); Ginsburg, Sexual Equality Under the Fourteenth and Equal Rights Amendments, 1979 WASH. U.L.Q. 161, 161 ("[T]he framers of the fourteenth amendment did not contemplate sex equality."); Crozier, Constitutionality of Discrimination Based on Sex, 15 B.U.L. REv. 723, 725 (1935) ("[I]t cannot be contended that there was even the faintest shadow of positive intent that the [Fourteenth Amendment] should apply to women.").

5. See infra note 78 . 
this simplistic view of the framers' intent. It might also support a more progressive interpretation of the Amendment in sex discrimination cases-to the extent that certainty about the framers' intent determines the level of scrutiny which courts apply.

\section{The Fourteenth Amendment's Framing}

\section{A. The Congressional Debates}

In the summer of 1865, Susan B. Anthony spotted a newspaper report of a proposed version of the Fourteenth Amendment, a version much like the one which was eventually ratified. The first section seemed agreeable. It promised all persons due process and equal protection under the law, and protected all citizens' privileges and immunities. ${ }^{6}$ The second section, however, seemed a catastrophe for the cause of women's suffrage. Under the second section, when a state denied men the right to vote, its basis of representation was reduced by the ratio of men denied the vote to the total number of men in the state. ${ }^{7}$ This section was designed to penalize Southern states that refused to enfranchise newly freed slaves. ${ }^{8}$ But because it implied that only men could vote, Anthony and other suffragists believed that it would constitutionalize women's disfranchisement. ${ }^{9}$ As Elizabeth Cady Stanton put it, "If that word 'male' be inserted [into the Constitution], it will take us a century at least to get it out."10

As soon as Anthony and Stanton learned of the Fourteenth Amendment's proposed language, they began raising money and orchestrating support for a campaign against the Amendment's second section. Anthony and Stanton devoted their 1865 Christmas holidays to "writing letters and addressing appeals and petitions to every part of the country."11 A vituperative debate over the Amendment's second section appeared in the nation's newspapers, ${ }^{12}$ and the debate quickly reached the floor of Congress.

6. U.S. CoNST. amend. XIV, $\$ 1$ ("All persons born or naturalized in the United States and subject to the jurisdiction thereof, are citizens of the United States and of the State wherein they reside. No State shall make or enforce any law which shall abridge the privileges or immunities of citizens of the United States; nor shall any State deprive any person of life, liberty, or property, without due process of law; nor deny to any person within its jurisdiction the equal protection of the laws.").

7. U.S. Const. amend. XIV, \& 2.

8. H. Flack, The Adoption of the Fourteenth amendment 98 (1908).

9. A. Lutz, Susan B. Anthony: Rebel, Crusader, Humanitarian 121 (1959). The Amendment did not literally deny women the vote. It just penalized states for disfranchising men, but did not penalize them for disfranchising women. The suffragists were alarmed by the Amendment's likely practical effect: They were sure that it would provide constitutional justification for the status quo.

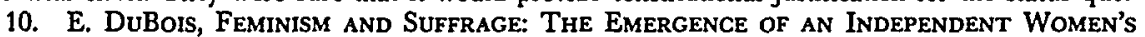
Movement IN AMERICA, 1848-1869, at 61 (1978), quoting letter from Stanton to Gerrit Smith, January 1, 1866.

11. E. Stanton, Eighty Years and More: Reminiscences 1815-1897, at 243 (1898).

12. See The History of Women's Suffrage II (E. Stanton, S. Anthony \& M. Gage eds. 1969) [hereinafter HWS]. The Albany Evening Journal pictured the Amendment's opponents with "hook-billed noses, crow's-feet under their sunken eyes, . . . a mellow tinting of the hair . . . [and] spectacles," and expressed pity for the "weaker vessels" who were their husbands. Id. at 101. The 
By January of 1866 , more than 10,000 supporters of women's rights had written to their Congressmen to protest the Fourteenth Amendment's second section. According to the suffragist Carrie Chapman Catt, "Few Senators or Representatives escaped a bombardment of letters and petitions urging that the nation should take no such backward step as to write the word male into the Constitution."13 In addition, "[t]wice resolutions were passed and delivered to Congress, fortifying the appeals that were being sent by petition. An address to Congress prepared by Miss Anthony was also . . . laid upon the desk of every Senator and Representative."14 This paper deluge was then followed by "[i]nterviews with Congressmen, begging them to heed the petitions which were pouring in . . .."15

In Congress, the suffragists' arguments were usually received without enthusiasm. ${ }^{16}$ Nevertheless, historians say that the suffragists' campaign "made its presence felt in the deliberations."17 Petitions protesting the Amendment's second section were presented on the floor of Congress at least five times in January and February of $1866 .{ }^{18}$ On one occasion, debate over the petitions was interrupted by so much applause from the "large number of persons" in the galleries and the representatives on the floor that the Speaker of the House had to reprimand both groups for their lack of decorum. ${ }^{19}$

The suffragists' palpable presence in Congress during the debates over the Fourteenth Amendment indicates that the Amendment's framers were kept aware of women's political concerns. It is true that the framers had little respect for the suffragists' arguments and that black rights remained

New York Tribune was convinced that "the sure panacea for such ills as the . . petitioners complain of, is a wicker-work cradle and a dimple-cheeked baby." Id. The Nation dismissed the campaign, declaring that many women did not really want suffrage. Id. at 102. The New York Independent, however, railed against the injustice of the Fourteenth Amendment's second section, and other papers printed letters from the suffragists themselves. Id. at 92-95.

13. C. Catt \& N. Shuler, Woman Suffrage and Politics: The InNer Story of the Suffrage Movement 37 (1923).

14. Id. at 39 .

15. Id. at 41; see also J. James, The Framing of the Fourteenth Amendment 130 (1956) (suffragists waged "a vigorous fight" against second section).

16. J. James, supra note 15 , at 130 . Although the Republicans seemed the suffragists' natural allies, few showed any but the most cursory interest in their cause. H. Trefousse, THE Radical Republicans 27 (1969). Representative Thaddeus Stevens of Pennsylvania refused to present a petition organized by Elizabeth Cady Stanton. See A. LuTz, supra note 9, at 118. Senator Charles Sumner of Massachusetts presented one from her ally Lydia Maria Child under protest, remarking that it was "most inopportune." HWS, supra note 12, at 95-97. So the suffragists turned to the Democrats, who "treated the petitioners with respect, and called attention in every way to the question." Id. at 95. Historians believe, however, that the Democrats did so merely to harass the Republicans. J. JAMEs, supra note 15, at 62; G. MYrdal, AN AMerican Dilemma 1076 (1962).

17. See, e.g., J. BAER, supra note 3, at 90 .

18. Petitions were presented by Representative Brooks on January 23, Senator Brown on January 24, Senator Henderson on February 21, Senator Sumner in late February, and Senator Lane on an unknown date. Cong. Globe, 39th Cong., 1st Sess. 380, 390, 951-52 (1866); HWS, supra note 12, at $96,101$.

19. Cong. Globe, 39th Cong., 1st Sess. 380 (1866). The applause was sparked by Representative James Brooks, Democrat of New York, who commented that when it came to extending the franchise he preferred white women to blacks. Id. 
uppermost in their minds. But if suffragist petitions jammed congressional mailboxes and noisy women overflowed the galleries, it is difficult to argue, as many do, that the framers hadn't given much thought to the demands of other politically disadvantaged groups.

Not only were the framers made aware of women's political concerns by the suffragist's petitions; comments made during the debates also suggest that many of them foresaw the use of the Fourteenth Amendment in sex discrimination cases. According to one historian, "[o]pponents of the amendment frequently pointed . . . out" that "the language of Section I, on its face, was broad enough to protect women as well as racial minorities."20 But the threat that women might file sex discrimination suits did not prevent a majority of Congress from supporting the Amendment. Nor did it lead supporters to defend the Amendment by claiming that it did not reach sex discrimination, even when they were pressed to do so. ${ }^{21}$

Comments made during the debates indicate that some of the framers were not averse to women claiming rights under the Fourteenth Amendment's first section. Why, then, were the framers almost unanimously indifferent to the suffragists' protest against the Amendment's second section? In 1866, many members of Congress perceived a great gulf between civil rights, like the right to personal security or ownership of property, and political rights, like the right to vote. ${ }^{22}$ Though the concept is foreign to us, many framers believed that certain adults deserved civil rights, but

20. J. BAER, supra note 3 , at 90 .

21. In an attempt to dissuade the Amendment's supporters, Representative Robert Hale, Republican of New York, argued that the Amendment's "vague, loose, and indefinite" language would violate principles of federalism by giving Congress the power to legislate in areas traditionally reserved to the states. For example, Hale said, the Fourteenth Amendment would give Congress the power to assure married women the same property rights as men. CoNG. GloBE, 39th Cong., 1st Sess. 1064 (1866). Representative Thaddeus Stevens, one of the most prominent members of the committee that drafted the Amendment, J. BAER, supra note 3, at 76, replied that as Iong as all married women were treated alike, and all men were treated alike, then there would be no violation of the Fourteenth Amendment. Hale's apt rejoinder was that under Stevens' interpretation of the Amendment, states could treat blacks differently from whites, as long as all blacks were treated alike. Id. Hale's point was hard to dispute: The Fourteenth Amendment's loose language did seem to allow Congress to challenge differential treatment of women and men. Stevens' most effective reply would have been to claim that the Amendment concerned only blacks and whites, but he did not use this argument.

If supporters had tried to defend the Amendment by claiming that it did not reach sex discrimination, they may have sparked protest from some of their colleagues: At least one framer implied during the debates that sex discrimination claims were within the reach of the Fourteenth Amendment. In one exchange, Representative James Brooks, Democrat of New York, asked why women "are not permitted to be represented under this resolution." Representative Roscoe Conkling of New York replied "They are . . . I thought they were persons." Cong. Globe, 39th Cong., 1st Sess. 379 (1866).

22. See H. Hyman \& W. Wiecek, Equal Justice Under LaW: Constitutional DevelopMENT 1835-1875, at 299, 395-97 (1982) (describing nineteenth-century vision of three different levels of rights which, ultimately, were granted to blacks in succession: first civil rights, like right to contract, sue, travel, own property, enjoy protection from violence; then political rights, like voting and officeholding; then social rights, like right to public accommodations, integrated public education, and intermarriage); Tushnet, The Politics of Equality in Constitutional Law: The Equal Protection Clause, Dr. Du Bois, and Charles Hamilton Houston, 74 J. AM. Hist. 884, 886-88 (1987) (Reconstruction lawmakers distinguished civil rights from political rights from social rights). 
not political rights. ${ }^{23}$ Many framers, then, could easily have tolerated nebulous demands for "women's rights," and at the same time implacably opposed women's suffrage. ${ }^{24}$ This theory is supported by evidence that during debates over the Fourteenth Amendment, Congressmen restricted their negative comments on women's rights to the question of the vote. ${ }^{25}$ These comments are quoted by scholars who wish to prove that the framers did not intend the Fourteenth Amendment to reach sex discrimination. ${ }^{26} \mathrm{But}$ all that is certain about the framers intent is that most of them did not want women to vote. When all the framers' comments on women are read together, they suggest that women's rights, short of suffrage, were thought to be within the reach of the Fourteenth Amendment.

\section{B. The Political Context}

The suffragists' presence in Congress during debates on the Fourteenth Amendment alerted the framers to women's political concerns-alerted them, in other words, to the Amendment's place in the political context of the 1860's. This context may have colored the Amendment's meaning in two ways. First, by 1866, as never before in American history, progressive people considered women worthy of new rights, and moderates and conservatives at least knew that increasing numbers of women were eager to acquire new rights. As a result, people of all political stripes assumed that women would claim inclusion in any general grant of rights, unless they

23. Some members of the 39 th Congress were more inclined to grant blacks civil rights than political rights. As a result, the arguments in favor of the civil rights bills debated in 1866 focused on the fact that the proposed legislation would not give blacks political rights. See ConG. GLOBE, 39th Cong., 1st Sess. 1151 (1866) (remarks of Rep. Martin Thayer, Republican of Pennsylvania); id. at 1117 (remarks of Rep. James Wilson, Republican of Iowa).

By contrast, Congress did intend the Fourteenth Amendment to extend to political as well as civil rights. Van Alstyne, The Fourteenth Amendment, the "Right" to Vote, and the Understanding of the Thirty-Ninth Congress, 1965 SuP. Cr. REv. 33, 85. At first glance, this point might seem inconsistent with the Note's argument that the framers did not preclude application of the Amendment to sex discrimination-given that some of the framers clearly opposed giving political rights to women. The two arguments, though, are not really inconsistent. The evidence suggests that there was a great deal of support in the 39th Congress for equal civil rights for blacks; some support for equal political rights for blacks and equal civil rights for women; and the least support for equal political rights for women. We can argue, then, that the framers did not preclude application of the Amendment to either political rights or sex discrimination, and still acknowledge that many framers opposed giving women the vote-in other words, that they opposed extending the Amendment in both directions at once.

24. Many framers may have shared the views of Senator Matthew Carpenter-who was not yet in Congress in 1866-who believed both that the Fourteenth Amendment did not guarantee women the vote and that the amendment reached sex discrimination. In 1872, Senator Carpenter wrote a report for the Senate Judiciary Committee which denied that women were guaranteed suffrage by the Fourteenth Amendment. See infra note 48 and accompanying text. In the same year, Carpenter argued before the Supreme Court that the Fourteenth Amendment guaranteed women the right to practice law, saying, "[A]ll the privileges and immunities which I vindicate to a colored citizen, I vindicate to our mothers, our sisters, and our daughters." Bradwell v. Illinois, 83 U.S. (16 Wall.) 130, 137 (1872).

25. See Cong. Globe, 39th Cong., 1st Sess. 952 (1366) (remarks of Sen. Henderson); id. at 40 (remarks of Sen. Morrill); id. at 56 (remarks of Sen. Williams); id. at 79 (remarks of Sen. Davis); id. at 297 (remarks of Rep. Schenck).

26. See, e.g., J. BAER, supra note 3 , at 91. 
were explicitly barred by the use of the word "male." Second, the questions of women's rights and black rights had been intertwined for many years in the minds of suffragists and some abolitionists. These reformers were therefore very likely to press courts with the claim that the Fourteenth Amendment was equally applicable to women and blacks-as, in fact, they did. ${ }^{27}$ Given that women were eager to claim new rights, and that many reformers considered women's rights and black rights an indivisible cause, it seems implausible that the framers wished to limit the Fourteenth Amendment to racial discrimination claims, but did not make this limitation explicit.

Since the ground-breaking Seneca Falls Convention of 1848, the leaders of the American women's movement had become increasingly adept at articulating their demands and organizing support. The growing power of the women's movement explains why the framers wrote the word "male" into the Constitution in the first place. As one historian put it, "Two decades of women's rights agitation had destroyed the centuries-old assumption that political rights applied only to men. Accordingly, the Republican authors of the Fourteenth Amendment ... had to decide between enfranchising women or specifying male citizens as the basis of representation." ${ }^{28}$ In Elizabeth Cady Stanton's account, a friend privy to the drafters' deliberations on the Amendment's second section related that "[o]ne of the committee proposed 'persons' instead of 'males.' 'That will never do,' said another, 'it would enfranchise wenches." "29

Some framers did not wish to antagonize women by appearing to constitutionalize their disfranchisement. But they knew that "the only way they could open the constitutional door just wide enough to let the black man pass in was to introduce the word 'male' into the national Constitution." "Chorles Sumner said, years afterward, that he wrote over nineteen pages of foolscap to get rid of the word 'male' and yet keep 'negro suffrage' as a party measure intact; but it could not be done."31 Senator Sumner was not just wasting foolscap. Presumably the last thing he wanted to see was a repeat of what had just befallen Australia:

Carelessly enough, [Australia's] male legislators omitted the significant adjective from their constitutional amendment, and, without a

27. See infra Section II.

28. E. DuBors, supra note 10 , at 60 .

29. E. Stanton, supra note 11 , at 242 .

30. Id.; see also C. CATT \& N. SHULER, supra note 13, at 43-44 ("Every argument which could be made for Negro suffrage applied to women. . . . The Negro was making little demand for the vote. The women were making an unprecedented one. How to get the Negro in and keep the women out constituted an ever present conundrum [for the Fourteenth Amendment's framers].").

31. Id. Sumner was not opposed to women's suffrage per se, but he feared that a constitutional amendment which implied that women had the right to vote would never succeed in Congress. Like most abolitionists, Sumner was willing to sacrifice women's suffrage in this, "the negro's hour." See infra note 38 . 
word of warning, on election day, every woman, properly qualified, was found at the polls. There was no just reason for refusing them the privilege, and The London Times says the precedent is to stand..$^{32}$

These accounts indicate that by 1866 increasing numbers of women assumed that they were included in any general grant of rights, unless the word "male" was explicitly used. This was not the assumption in earlier years, so the word "male" had never before been written into the Constitution. $^{33}$ The word "male," of course, was not used in the Fourteenth Amendment's first section. This omission might not have meant much in 1787. But these accounts of the framing indicate that the omission of the word "male" and the use of the general terms "persons" and "citizens" meant a great deal by 1866. When viewed in its political context, the different language used in the Amendment's two sections supports the interpretation proposed above: The framers were willing to allow the Fourteenth Amendment to reach questions of women's rights, short of suffrage..$^{34}$

Not only were many women thought to want new rights in 1866, but anyone familiar with the progressive political culture of the day knew that suffragists and some abolitionists considered women's rights intimately related to black rights. ${ }^{35}$ Since the 1830 's, reformers had spoken of slavery

32. HWS, supra note 12, at 102, (quoting Letter to The Nation from Caroline Healy Dall, Jan. $6,1866)$. Some of the framers, at least the abolitionists among them, must have known that the same problem had confronted the country's most prominent abolitionist organization in the late 1830's. The American Anti-Slavery Society's constitution said that "persons" who supported it financially and subscribed to its principles could be members. All members could vote, speak at meetings, and serve on committees. Several years after the document was written a battle ensued, with one faction claiming that women were persons, and the other relying on an original intent argument that the constitution's framers said "persons," but meant "men." Women were finally included in "persons" for the purpose of interpreting the constitution, but the fight was so fierce that it permanently split the Society in two. A. Kraditor, Means and Ends in AMERICAN Abolitionism 48-49 (1967).

33. This statement does not imply that all the rights guaranteed in the 1787 Constitution were guaranteed only to men. Under the original Constitution, women had certain rights, like freedom of speech, and did not have others, like suffrage. In 1787, there was no need to spell out the distinction, because women were not so restive that they seemed likely to press courts to interpret generally phrased constitutional guarantees in their favor. The difference was that by 1866 women were that restive, and Congress knew it.

34. The difference between the language in section 1 and section 2 may be a particularly reliable indicator of the framers' intent because there is evidence that the language of the two sections did not differ accidentally. In an early version of the Amendment, the language of the two sections was quite similar. An early first section prohibited discrimination because of race, color, or previous condition of servitude. B. KendRICK, The Journal of the Joint CommitTEe of Fifteen on ReConstrucTION 83 (1914). An early second section reduced a state's basis of representation if it denied suffrage because of race, color, or previous condition of servitude. Id. at 84 . But in the version of the Amendment that was eventually presented to Congress, the language of the first section had changed considerably, abandoning its narrow focus on race in favor of equal protection for all "persons." Id. at 106. By contrast, the second section focused on race in both earlier and later versions: It always penalized states for disfranchising blacks, but did not penalize them for disfranchising women. Id. at 84, 102. The Amendment's drafters, then, deliberately altered the language of section 1, thereby distinguishing it from section 2 .

35. In the late 1830 's, the abolitionist leader William Lloyd Garrison began to believe that the doctrine of women's rights was "bound up with the cause of human freedom." G. BARNES, THE 
and women's predicament in the same breath. ${ }^{36}$ When the Civil War began, Anthony and Stanton established the Women's National Loyalty League so that the war would "be fought . . . not only for the one-sixth in racial bondage but the one-half in sexual oppression." ${ }^{37}$ After the war, the political bond between advocates of women's rights and advocates of black rights began to disintegrate. ${ }^{38}$ But this post-war rift was largely a

ANTISLAVERY IMPULSE 155 (1933). So Garrison announced that his paper, The Liberator, would thenceforth advocate women's rights as well as abolition. R. NYE, William Llovd GarRISON AND THe Humanitarian Reformers 113 (1955). Shortly thereafter, Garrison split the American AntiSlavery Society in a battle over women's right to full participation in society meetings, A. KRADITOR, supra note 32, and he conspicuously joined his female allies when they were relegated to the gallery in the 1840 London convention of the World Anti-Slavery Society. L. LADER, ThE Bold Brahmins: New England's War Against Slavery: 1831-1863, at 57 (1961). Frederick Douglass also saw himself engaged in a struggle for human rights, not just black rights, and therefore took an active role in the women's movement. Quarles, Abolition's Different Drummer: Frederick Douglass, in $\mathrm{M}$. Duberman, The Antislavery Vanguard: New Essays on the Abolitionists 123, 132-33 (1965). And at the Free Soil convention of 1852, Gerrit Smith and other abolitionists sought endorsement of equal political rights for blacks and women-though only a handful of delegates actually voted for the proposed plank. R. Sewell, Ballots For Freedom: Antislavery Politics in the UNITED STATES, 1837-1860, at 245 (1976). Some historians claim that the abolitionists' adherence to women's rights was only skin deep, see A. KRADrTor, supra note 32, at 53-59, and others emphasize the views of abolitionists who thought that tangling women's rights with black rights was either politically hazardous, or wrong in principle. See R. WALTERS, AMERICAN Reformers 1815-1860, at 89 (1978); R. Walters, The ANTislavery Appeal: American Abolitionism After 1830, at 11-12 (1976); G. BARNES, supra, at 160.

36. Abby Kelley declared that she was grateful to the slave, because "[i]n striving to strike his irons off, we found most surely that we were manacled ourselves." FREEDOM, FemInISM AND THE State: An Overview of Individualist Feminism 4 (W. McElroy ed. 1982) (quote undated). Kelley's husband, Stephen Foster, remarked that "every family is a little embryo plantation, and every woman is . . . in the eye of her husband . . . a slave, and the breeder of slaves." L. PERRY, RADICAL Abolitionism: ANarchy and the Government of God in Antislavery Thought 230 (1973) (quoting Speech by Stephen Foster, Rutland, Vermont Free Convention of 1858). Frances Gage wondered how anyone could expect an earnest anti-slavery effort "while nearly every man in the country over twenty-five years of age owns one pair of hands." CHWS, supra note 1, at 6 (quoting Letter from Frances Gage to The Liberator (Dec. 28, 1860)).

Participants at the Seneca Falls Convention later wrote of the year 1848: "At this time the condition of married women under the Common Law, was nearly as degraded as that of the slave on the Southern plantation." CHWS, supra note 1, at 97. Sarah Grimké compared Blackstone's statement that women have no legal existence apart from their husbands to slaves' similar legal status. $S$. Grimké, LetTers on the Equality of The SEXes and THE Condition of Women 79-83 (Letter XII) (1837). And Angelina Grimké stated the theoretical basis for all these comments: Wife-status and slave-status were similarly intolerable because all people, black and white, women and men, had the same rights. Grimké, Human Rights Not Founded on Sex, in Freedom, Feminism and the STATE, supra, at 29.

37. CHWS, supra note 1, at 193 (quoting the editors, not the suffragists). The League's initial resolutions, adopted in New York City in May 1863, included a call for the practical establishment of civil and political rights for all blacks and all women. CHWS, supra note 1, at 199. In debates over this resolution, women spoke passionately, to loud applause, about the identification of the two causes. Lucy Stone urged soldiers, "While you are going through this valley of humiliation, do not forget that you must be true alike to the women and the negroes." Id. at 207. Ernestine Rose insisted that in "a republic based upon freedom, woman, as well as the negro, should be recognized as an equal with the whole human race." Id. at 202. Susan B. Anthony asked, "[I]s it possible for this Government to be a true democracy, a genuine republic, while one-sixth or one-half of the people are disenfranchised?" Id. at 203. And Angelina Grimké added, "I rejoice exceedingly that that resolution should combine us with the negro. I feel that we have been with him; that the iron has entered into our souls. True, we have not felt the slave-holder's lash; true, we have not had our hands manacled, but our hearts have been crushed." Id. at 202 (from speeches delivered in May and September, 1863). The resolution uniting women's rights with black rights was carried by a large majority. Id. at 208.

38. After the war, national attention focused on black suffrage. Abolitionists suddenly distin- 
tactical dispute between abolitionist and suffragist leaders; women's rights and black rights were still linked conceptually in the minds of many reformers. ${ }^{39}$ In May 1866, one month before Congress voted on the Fourteenth Amendment, suffragists and abolitionists gathered to reunite their efforts. A new organization was founded, the American Equal Rights Association (A.E.R.A.), whose purpose was "burying the black man and the woman in the citizen." ${ }^{240}$ One of the A.E.R.A.'s first acts was to send an address to Congress to protest the second section of the Fourteenth Amendment, ${ }^{41}$ because, as the address said, denying either women or blacks the right to vote was a "violation[] of the republican idea." 22 The organization's preamble and resolutions, which equated the political condition and aspirations of women and blacks, were quoted in the popular press. ${ }^{43}$ The A.E.R.A.'s philosophy was also expressed on the floor of

guished their primary goal, black rights, from their more general, less pressing goals, like women's rights. E. DuBoIs, supra note 10, at 55. Wendell Phillips, in assuming the leadership of the powerful American Anti-Slavery Society in 1865, announced, "This hour belongs to the negro." Id. at 59 (quoting American Antislavery Standard, May 13, 1865, at 2). Gerrit Smith, for many years a crusader for black and women's rights, refused to sign a petition to Congress which asked that no distinction be made between women and men in constitutional amendments which referred to suffrage. Elizabeth Cady Stanton, Susan B. Anthony: Correspondence, Writings, Speeches 119-20 (E. Du Bois ed. 1981). A formal break between the suffragists and abolitionists occurred in the spring of 1866 , at a small meeting in Boston, when Wendell Phillips said that it was time to strike the word "white," from the Constitution, but not the word "male." Theodore Tilton, editor of The New York Independent and the suffragists' longtime ally, agreed. Anthony swept angrily from the room, and Stanton later declared that she was through "boosting the Negro over her own head." Anthony and Stanton decided that they would henceforth devote their energies only to women's suffrage. A. LuTZ, supra note 9 , at 120 .

39. G. Mykdal, supra note 16 , at 1076. As Stanton described the link between women's rights and black rights:

[T] he disfranchised all make the same demand, and the same logic and justice that secures suffrage to one class gives it to all. The struggle of the last thirty years has not been merely on the black man as such, but on the broader ground of his humanity. . . . If our rulers have the justice to give the black man suffrage, woman should avail herself of that new-born virtue to secure her rights....

HWS, supra note 12, at 94-95 (quoting Letter to The Antislavery Standard (Dec. 26, 1865)).

40. HWS, supra note 12, at 174. While it lasted, the A.E.R.A. was an impressive organization. Among its officers and activists, the largest group were women who had worked on women's rights for two decades with the American Anti-Slavery Society, including Anthony, Stanton, Lucy Stone, Lucretia Mott, Ernestine Rose, and Frances Gage. There were also prominent abolitionist men: Henry Ward Beecher, one of the most powerful clergymen in the country, spoke at the A.E.R.A.'s founding, and Frederick Douglass, Stephen Foster, Theodore Tilton and others were allied with the organization throughout its short life. E. DuBors, supra note 10, at 67-68. These leaders were joined by prominent women abolitionists who had not worked on women's rights before the war. Id. at 68 . The A.E.R.A. operated as a national organization, and also formed local groups in six states and Washington, D.C. From these bases, the A.E.R.A. launched a series of lobbying and petitioning campaigns to remove racial and sexual restrictions from the constitutions of six different states. These included New York, where in 1867 the A.E.R.A. held meetings in each of the state's sixty counties and presented 28,000 signatures to the delegates at a constitutional convention. Id. at 64-70. Three years after the A.E.R.A. began, however, it succumbed to the same disagreements between suffragists and abolitionists that had occasioned its founding. Id. at 77. See supra note 38 on the disagreements between suffragists and abolitionists.

41. CHWS, supra note 1 , at $226-29$.

42. Id. at 228 .

43. The New York Herald printed the A.E.R.A.'s preamble, including the statement that "negroes and women now hold the same civil and political status, alike needing only the ballot." The Herald also printed the association's resolutions, including the following: "[L]iberty and equality are the in- 
Congress at the same time that the Fourteenth Amendment was debated: Considering a proposal that the District of Columbia extend suffrage to women as well as to blacks, several members of Congress discussed the similarity between the political conditions of the two groups. ${ }^{44}$

The conceptual link between women's rights and black rights, first articulated in the 1830's, held firm in the minds of reformers through the spring of 1866. This link would have been apparent to any of the Fourteenth Amendment's framers who read his mail, who read the popular press, or who listened to his progressive colleagues. The framers might easily have guessed, then, that reformers would read the Fourteenth Amendment as equally applicable to women and blacks, and that they would press courts to accept their interpretation.

Apparently, when the Fourteenth Amendment's framers wished to pry women's rights from black rights, they felt compelled to use explicit language; that is why they were careful to insert the word "male" into the Amendment's second section. The Amendment's first section, however, refers only to "persons" and "citizens." It would be natural to infer from this textual difference alone that the framers were willing to allow the Amendment's first section to reach sex discrimination. We can also say that the Amendment's history supports this inference. The suffragists' petitions and the Amendment's political context put the framers on notice that some people would assume that the Amendment reached sex discrimination. Yet the framers did not explicitly preclude sex discrimination claims. This suggests that scholars have spoken too quickly in arguing, for example, that there was not "the faintest shadow of positive intent that the [Fourteenth Amendment] should apply to women."

\section{EARLY INTERPRETATIONS}

Early interpretations of the Fourteenth Amendment by the Supreme Court, lower federal courts, state courts, and Congress-which included many of the Amendment's framers-almost unanimously agreed that the Amendment reached sex discrimination. Shortly after the Amendment's ratification, Congress and the courts began hearing sex discrimination

herent rights of man in civilization; and no constitution or code should be accepted as law that does not secure them to every citizen. The same arguments apply equally to both [negroes and women], and prove that all partial legislation is death to republican institutions." New York Herald, May 11, 1866.

44. In the December 1865 debates on suffrage in the District of Columbia, Senator Cowan of Pennsylvania said, "A great many reflections have been made upon the white race keeping the black in slavery. I should like to know whether we have not partially kept the female sex in a condition of slavery . . . "HWS, supra note 12, at 105. In debates on the same issue in the House, Representative Boyer said, "If the negro has a natural right to vote because he is a human inhabitant of a community professing to be republican, then women should vote for the same reason. . . . CoNG. Globe, 39th Cong., 1st Sess. 177 (1866), reprinted in The Reconstruction Amendments' DeBATES 101 (A. Avins ed. 1974).

45. Crozier, supra note 4. 
claims under the Fourteenth Amendment-in the sense that the merit of these claims was determined by meticulous interpretation of the Amendment's text and the Amendment's relation to other constitutional provisions. Congress and the courts could not have reached these interpretive issues without first deciding, as a threshold question, to hear sex discrimination claims under the Fourteenth Amendment. If the Fourteenth Amendment simply did not reach sex discrimination, Congress and the courts would have dismissed the petitions and lawsuits for reasons analogous to the modern "failure to state a claim." But Congress and most courts did not take this approach, suggesting that in the nineteenth century no one doubted that the Amendment reached sex discrimination, at least in theory.

\section{A. Interpretations by Congress}

After the defeat of the suffragists' campaign against the Fourteenth Amendment's second section, the movement's leaders decided that the first section was ripe for use. In 1870, Senator Ira Harris and Representative George Julian presented a memorial to Congress from the suffragist Victoria Woodhull. Woodhull asked that Congress use its power to enforce the Fourteenth Amendment to prevent the states from disfranchising women. ${ }^{46}$ The memorial was referred to the House Judiciary Committee, which issued majority and minority reports in $1871 .{ }^{47}$ Neither report, nor a report on the same question issued in 1872 by the Senate Judiciary Committee, ${ }^{48}$ so much as suggested that sex discrimination was beyond the reach of the Fourteenth Amendment.

Both the House Judiciary Committee's majority report and the Senate Judiciary Committee's report concluded that denying women the vote did not violate the Fourteenth Amendment. The House Committee's majority report argued that women were citizens, but that voting was not a "privi-

46. HWS, supra note 12 , at $443-44$. In addition to presenting memorials to Congress, suffragists also cast over a hundred ballots in 1871 and 1872, believing that the Fourteenth Amendment had given them the right to vote. Hoff-Wilson, The Legal Status of Women in the Late Nineteenth and Early Twentieth Centuries, 6 Human Righrs 125, 130 (1977). In 1870, black women voted in South Carolina, encouraged to do so by federal agents. According to one historian, "that [women] attempted to vote and were permitted to do so by elections officials suggests [that the suffragists' interpretation of the Fourteenth Amendment was] widespread, even popular." DuBois, Outgrowing the Compact of the Fathers: Equal Rights, Woman Suffrage, and the United States Constitution, 74 J. AM. Hisr. 836, 853 (1978).

47. H.R. Rep. No. 22, Cong. Globe, 41st Cong., 3d Sess. (Jan. 30, 1871) (written by Rep. John Bingham), reprinted in The Reconstructron Amendmen's' Debates, supra note 44, at 466-67 [hereinafter House Majority RePoRT]; H.R. Rep. No. 22, pt. 2, Cong. Globe, 41st Cong., 3d Sess. (Feb. 1, 1871) (written by Reps. William Loughridge and Benjamin Butler), reprinted in THE ReConstruction AMENDMENTS' Debates, supra note 44, 467-71 [hereinafter HOUSE MINORITY REPORT].

48. S. Rep. No. 21, Cong. Globe, 42d Cong., 2d Sess. (Jan. 25, 1872) (written by Sen. Matthew Carpenter), reprinted in The Reconstruction AMendments' Debates, supta note 44, at 572-73 [hereinafter SENATE REPORT]. 
lege or immunity" guaranteed to citizens by the Fourteenth Amendment. ${ }^{49}$ Both the House Committee's majority report and Senate Committee's report also argued that the states' ability to disfranchise women was implied by the Fourteenth Amendment's second section and the Fifteenth Amendment. The former, they said, was riddled with the word "male." The latter prevented states from denying the vote on the basis of race, color, or previous condition of servitude, implying that states could deny the vote on any other grounds. ${ }^{30}$ The Senate Committee's report argued further that the Fifteenth Amendment would have been superfluous if the Fourteenth Amendment had guaranteed citizens the right to vote. ${ }^{\text {s1 }}$

The House Committee's minority report agreed with the suffragists that denying women the vote violated the Fourteenth Amendment. The report argued that all the privileges and immunities due men were due women as well; that voting was a privilege or immunity guaranteed by the Fourteenth Amendment; and that women were not implicitly disfranchised by the Fourteenth Amendment's second section or the Fifteenth Amendment.

The debate between the House Committee's majority report and the Senate Committee's report, on the one hand, and the House Committee's minority report, on the other hand, was quite limited in scope. It concerned only whether voting was a privilege or immunity, and what the Fifteenth Amendment and the Fourteenth Amendment's second section implied about women's suffrage. On one point all three reports were in full, if implicit, agreement: The Fourteenth Amendment did reach sex discrimination.

In addition to Congress' disposition of the suffragists' petitions, other evidence from the 1870's indicates that many Congressmen believed the Fourteenth Amendment reached sex discrimination. When Congress debated a bill in 1874 that would have prohibited the exclusion of blacks from a number of public institutions, including public schools, ${ }^{52}$ the bill's proponents claimed that the Fourteenth Amendment gave Congress the power to desegregate the schools. The bill's opponents disagreed. They argued that if the Fourteenth Amendment allowed Congress to put blacks

49. The majority report said that voting was not a privilege or immunity guaranteed by the Fourteenth Amendment because it was not among the privileges and immunities included in the original Constitution. The following year, the Supreme Court agreed with the majority report: "privileges and immunities" meant only those guaranteed by the original Constitution. Slaughter-House Cases, 83 U.S. (16 Wall.) 36 (1872). To decide whether voting was a privilege or immunity under the original Constitution, the House Committee's majority report relied on the 1823 decision Corfield v. Coryell, which included in its list of privileges and immunities "the elective franchise, as regulated and established by the laws or constitution of the state in which it is to be exercised." 6 F. Cas. 546, 551-52 (C.C.E.D. Pa. 1823). According to the majority report, following Corfield v. Coryell, voting rights were utterly dependent on state law and therefore were not a privilege or immunity. House MAJORITY REPORT, supra note 47.

50. Id.; SENATE REPORT, supra note 48.

51. Id. at 572 .

52. Cong. Globe, $43 d$ Cong., 1st Sess. 657 (1873). 
and whites in the same school, then the Amendment would allow Congress to put girls and boys in the same school. "I should like to hear anybody point out a legal difference," said one of the bill's opponents..$^{53}$ The clear implication of this argument, offered repeatedly, was that the Fourteenth Amendment applied to sex discrimination exactly as it applied to race discrimination. ${ }^{54}$

Interpretations of the Fourteenth Amendment by the Judiciary Committees and individual Congressmen provide convincing evidence of the framers' intent. Many members of Congress in the 1870's were in office during the passage of the Fourteenth Amendment. ${ }^{55}$ In addition, the House Committee's majority report on Victoria Woodhull's petition was written by Representative John Bingham, Republican of Ohio, the chief draftsman of the Amendment's crucial first section. ${ }^{5 B}$ In addressing the suffragists' petitions, Bingham and others examined the Amendment's text and its relation to other constitutional provisions rather than arguing that the Amendment did not reach sex discrimination; and in debates over school desegregation, Congressmen assumed that the Amendment applied equally to women and blacks. In the 1870's, then, Congress apparently believed that sex discrimination claims could be heard under the Fourteenth Amendment.

53. Id. at 313 (1874) (remarks of Senator Merrimon).

54. See id. at 4171-72 ("I do not know that the fourteenth amendment enjoins upon us that we shall have [racially] mixed schools. . . . I doubt if the fourteenth amendment provides that females shall be intruded into male schools or males into female schools; and yet this would be the office of the fourteenth amendment under the logic of the Senator from Vermont.") (remarks of Senator Sargent); id. at 313 ("I cannot understand or comprehend a distinction in point of principle between the power to educate the sexes in separate schools and that to require the races to be educated in separate schools.") (remarks of Senator Merrimon); id. at 428 ("The "equal protection of the laws' could not have been designed for any such case. It could never have been contemplated that every citizen, male and female, black and white, foreign and native, should be accorded the enjoyment of every right in the same measure and in the same degree. Such a construction would invalidate all legislation which separated the sexes in schools supported by public funds . . . .) (remarks of Representative Buckner); see also id. at 359 (remarks of Senator Merrimon); id. at 343 (1873) (remarks of Representative Beck); id. at 453 (remarks of Representative Atkins).

One proponent of the desegregation bill tried to dodge these arguments by claiming that the Fourteenth Amendment reached only racial discrimination, not sex discrimination. Congress, he said, therefore had the power to order racially integrated schools, but not sexually integrated schools. An opponent of the bill replied, "[T]he Constitution does not say anything about 'race' except in certain respects. It provides expressly that there shall be no discrimination on account of race or color as to the matter of voting. . . but there is no expression touching distinctions as to race in any other respect whatsoever." Id. at 359 (remarks of Senator Merrimon).

55. Of the 74 Senators in January 1872, when the Senate report was written, 25 , or one-third, were in Congress during the debates over the Fourteenth Amendment. Of the 257 Representatives in January 1871, when the House reports were written, 49, or one-fifth, were in Congress during the debates. BIOGRAPHiCAL Directory of the AMERICAN Congress, 1774-1971, at 184-87, 193-202 (1971). None of the Congressmen who discussed whether the Amendment applied to sex discrimination in the context of school desegregation were in Congress during the 1866 debates. Id. Their comments, then, are not a direct clue to the framers' intent. But their comments, like early judicial interpretations of the Amendment, do reveal how the framers' contemporaries perceived their intent.

56. Graham, The Early Antislavery Backgrounds of the Fourteenth Amendment, 1950 WIs. L. REV. 479, 481; see also J. JAMEs, supra note 15, at 81-83. 


\section{B. Judicial Interpretation}

The Supreme Court, lower federal courts, and state courts heard a number of sex discrimination claims under the Fourteenth Amendment in the late nineteenth and early twentieth centuries. These courts invariably ruled against women plaintiffs, but, with a single exception, they did not do so because the plaintiffs had failed to state a claim under the Fourteenth Amendment. Instead, in early cases decided under the privileges and immunities clause, the validity of the women's claims was determined by interpretation of the Amendment's text and its relation to other constitutional provisions. In later cases decided under the equal protection and due process clauses, courts decided that due to profound differences between the sexes, treating women and men differently was reasonable and therefore did not violate the Fourteenth Amendment. Whichever clause courts used, they always assumed that women could state claims under the Fourteenth Amendment, and they always used standard Fourteenth Amendment analysis to determine the validity of these claims.

In the first sex discrimination case, Bradwell v. Illinois, the Supreme Court decided that denying women admission to the bar did not violate the Fourteenth Amendment. ${ }^{67}$ Bradwell is remembered as an example of the Court's unwillingness to entertain sex discrimination claims under the Amendment, ${ }^{58}$ but this was not, in fact, what the case was about. The Court denied only one of Bradwell's claims: that admission to the bar was a privilege or immunity guaranteed to citizens by the Fourteenth Amendment. ${ }^{50}$ The Court did not deny Bradwell's other claim: that the Fourteenth Amendment protected the rights of women as well as blacks. As Bradwell's counsel stated the issue to the Court:

[A] State legislature could not, in enumerating the qualifications [for the bar], require the candidate to be a white citizen. This would be the exclusion of all colored citizens, without regard to age, character, or learning. Yet no sound mind can draw a distinction between such an act and a custom, usage, or law of a State, which denies this privilege to all female citizens, without regard to age, character, or learning. . . . [I]f [the privileges and immunities clause] does protect

57. 83 U.S. (16 Wall.) 130 (1872); see also In re Lockwood, 154 U.S. 116 (1894) (privileges and immunities clause was not violated when woman was denied admission to bar).

58. See, e.g., K. DeCrow, Sexist Justice 36 (1974) ("Until 1971, the Supreme Court had never decreed that women are 'persons' under the law and entitled to its equal protection."); $L$. WARSOFF, EQUALITY AND THE LAW 199 (1938) ("Just about one hundred pages earlier, in the same volume of the reports, Mr. Justice Miller decided the Slaughter-House Cases in which he made the statement that he doubted very much whether any state action not directed toward discrimination against the Negro, would ever come within the purview of the equal protection clause of the Fourteenth Amendment. Naturally enough, the petition in the [Bradwell] case was dismissed.").

59. Id. at 139. 
the colored citizen, then it protects every citizen, black or white, male or female. ${ }^{60}$

Bradwell's counsel challenged the Court to limit the Fourteenth Amendment to racial discrimination. And though the Court had declared just a few pages earlier in the Slaughter-House Cases that the Amendment's pervading purpose was to protect blacks, ${ }^{01}$ it declined to decide Bradwell on that ground.

A second Supreme Court case from the 1870's, Minor v. Happersett, ${ }^{62}$ was decided in much the same way as Bradwell. Minor claimed that the Fourteenth Amendment gave her the right to vote. The Court disagreed, basing its decision on the same arguments that the House and Senate Judiciary Committees had used to answer the suffragists' petitions. ${ }^{63}$ As in Bradwell, the Court never questioned the propriety of hearing Minor's sex discrimination claim under the Fourteenth Amendment. In fact, the Court believed that it could decide the case "upon other grounds," but agreed to decide it under the Fourteenth Amendment, as Minor requested, because "the question is fairly made."

In the 1870 's, lower federal courts also heard a number of women's suffrage cases under the Fourteenth Amendment. ${ }^{65}$ The most celebrated was Susan B. Anthony's 1873 criminal trial for voting. Anthony claimed that "[i]t has never, since the adoption of the Fourteenth Amendment, been questioned . . . that women as well as men are included in the terms of its first section, nor that the same 'privileges and immunities of citizens' are equally secured to both." ${ }^{\text {66 }}$ U.S. Supreme Court Justice Ward Hunt, riding circuit, agreed. He heard the case under the Fourteenth Amendment, stating explicitly that " $[\mathrm{t}] \mathrm{he}$ thirteenth, fourteenth, and fifteenth amendments were designed mainly for the protection of the newly emancipated negroes, but full effect must, nevertheless, be given to the language employed." tion-but there Anthony and Justice Hunt parted company. Hunt believed that privileges and immunities included only those rights guaranteed by the federal Constitution. Therefore suffrage, a right arising under

60. Id. at $135-36$.

61. 83 U.S. (16 Wall.) 36,71 (1872).

62. 88 U.S. (21 Wall.) 162 (1874).

63. See text accompanying notes 49-51.The Minor Court said that although women were citizens, voting was not a privilege or immunity guaranteed to citizens by the Fourteenth Amendment. It also said that both the Fourteenth Amendment's second section and the Fifteenth Amendment implied that the Fourteenth Amendment's first section did not guarantee all citizens the right to vote. Id. at $170-75$.

64. Id. at 165 .

65. HWS, supra note 12 , at 507 .

66. Account of the Proceedings on the Trial of Susan B. ANthony 36 (1874).

67. 24 F. Cas. 829, 829 (C.C.N.D.N.Y. 1873) (No. 14,459). 
state constitutions, was not protected by the privileges and immunities clause. ${ }^{68}$

In the nineteenth century, at least three state supreme courts also heard sex discrimination claims under the Fourteenth Amendment. ${ }^{69}$ In only one of these cases, decided in 1882 by the Wyoming Supreme Court, did a court say that a sex discrimination claim could not be heard under the Fourteenth Amendment because the Amendment prohibited racial discrimination but not sex discrimination. In the light of Bradwell and $\mathrm{Mi}$ nor, it appears that the Wyoming Supreme Court was not only shortsighted about the future; it was also bucking precedent.

In the early twentieth century, courts at all levels continued to hear sex discrimination claims under the Fourteenth Amendment, but with one difference: Because the Supreme Court held in 1872 that the privileges and immunities clause added nothing to the rights guaranteed by the Constitution's original text, ${ }^{70}$ lawyers challenging both sex discrimination and racial discrimination abandoned the privileges and immunities clause and began to use the equal protection and due process clauses. ${ }^{71}$ Still, challenges to sex discrimination were invariably denied. ${ }^{72}$ Under the equal

68. Id. at 830 .

69. The Ohio Supreme Court upheld an ordinance preventing liquor sellers from employing women other than their wives, without stating reasons. Bergman v. Cleveland, 39 Ohio St. 651 (1884); see also In re Considine 83 F. 157, 158 (C.C.D. Wash. 1897) (equal protection clause not violated by statute forbidding women to work where liquor was sold, because law applied equally to people similarly situated-implying that women and men are not similarly situated with respect to liquor sales). The Indiana Supreme Court decided under state law that women should be admitted to the bar, but included an aside indicating its willingness to hear sex discrimination claims under the Fourteenth Amendment. The court said that women are citizens whose privileges and immunities could not be abridged. It also said that women's right to practice law could not be denied simply because the Constitution's framers might not have anticipated that women would someday wish to practice law. In re Petition of Leach, 134 Ind. 665, 670, 667 (1893). The Wyoming Supreme Court upheld the exclusion of women from a jury because the Fourteenth Amendment was intended to prohibit racial discrimination, not sex discrimination. McKinney v. State, 3 Wyo. 719, 725-27 (1892).

70. 83 U.S. (16 Wall.) 36 (1872). See generally G. GuNTHER, supra note 2, at 417 (SlaughterHouse Cases eviscerated privileges and immunities clause); J. ELY, supra note 3, at 22-23 (same); R. Berger, Government By Judiciary 37-38 (1977) (same).

71. The history of the Fourteenth Amendment's use in racial discrimination cases parallels the history of its use in sex discrimination cases. For a few years after the Slaughter-House Cases, lawyers in racial discrimination cases, like the lawyers for Bradwell and Minor, stubbornly tried to breathe life back into the privileges and immunities clause. See, e.g., Walker v. Sauvinet, 92 U.S. 90 (1875). But when these claims did not succeed, lawyers in racial discrimination cases, like lawyers in sex discrimination cases, began making claims under the amendment's other clauses. See, e.g., Strauder v. West Virginia, 100 U.S. 303 (1879); Virginia v. Rives, 100 U.S. 313 (1879); Ex parte Virginia, 100 U.S. 339 (1879); Pace v. Alabama, 106 U.S. 583 (1882).

72. The Supreme Court upheld laws that forbade selling liquor to women, Cronin v. Adams, 192 U.S. 108 (1904); that taxed female and male laundry operators at different rates, Quong Wing v. Kirkendall, 223 U.S. 59 (1912); that limited the number of hours women could work, Dominion Hotel v. Arizona, 249 U.S. 265 (1919); Riley v. Massachusetts, 232 U.S. 671 (1914); Muller v. Oregon, 208 U.S. 412 (1908); that prohibited the employment of women in big-city restaurants at night, Radice v. New York, 264 U.S. 292 (1924); that established a minimum wage for women but not for men, West Coast Hotel Co. v. Parrish, 300 U.S. 379 (1937); that levied a poll tax on men but not women, Brcedlove v. Suttles, 302 U.S. 277 (1937); that forbade women to bartend unless they were wives or daughters of male bar owners, Goesaert v. Cleary, 335 U.S. 464 (1948); and that allowed women to volunteer for juries but did not press them into service, Hoyt v. Florida, 368 U.S. 57 (1961). 
protection and due process clauses, laws that treated women and men differently were held unconstitutional only if different treatment seemed unreasonable or arbitrary. At that time, of course, women and men were thought to be profoundly different creatures. ${ }^{73}$ Laws treating women and men differently seemed perfectly reasonable, and therefore did not violate the Fourteenth Amendment. ${ }^{74}$

It was not until the 1970's that the Court used the Fourteenth Amendment to strike down differential treatment of women and men. ${ }^{75}$ But this novel approach to sex discrimination was not the result of some doctrinal leap; it was not even the result of doctrinal evolution. The Court's new approach simply reflected changing social mores: Most classifications based on sex now seemed unreasonable. In sum, what distinguishes the sexist Fourteenth Amendment decisions of the 1870's from the feminist Fourteenth Amendment decisions of the 1970's and 1980's is simply judges' view of women. The doctrine-courts' willingness to judge differential treatment of women and men under the Fourteenth Amendment-has an unbroken history stretching back almost to the Amendment's ratification.

\section{Conclusion}

The evidence presented above shows that the Fourteenth Amendment's history is open to interpretation. It might be read to support the consensus view that the framers did not intend the Amendment to reach sex discrimination. After all, one could argue that the evidence presented in this Note is merely circumstantial, and that few Congressmen in the 1860's would deliberately have lent constitutional support to a cause that was still considered fairly radical. Yet, as this Note argues, scholars may have reached this conclusion too hastily.

In order to decide which interpretation of the Fourteenth Amendment's history is valid, it is crucial to know what is meant by intent. Some courts

73. See, e.g., Quong Wing, 223 U.S. at 63 ("If Montana deems it advisable to put a lighter burden upon women than upon men with regard to an employment that our people commonly regard as more appropriate for the former, the Fourteenth Amendment does not interfere by creating a fictitious equality where there is a real difference."); Muller, 208 U.S. at 422 ("Differentiated by lphysical structure and maternal functions] from the other sex, she is properly placed in a class by herself, and legislation designed for her protection may be sustained, even when like legislation is not necessary for men and could not be sustained.").

74. Hoyt, 368 U.S. at 62 (not requiring women to serve on juries is reasonable because of their "special responsibilities" for home and children); Goesaert, 335 U.S. at 466-67 (law forbidding women to bartend did not create unreasonable classification); Radice, 264 U.S. at 296 (prohibiting women from working in big-city restaurants at night is not unreasonable or arbitrary).

75. See, e.g., Frontiero v. Richardson, 411 U.S. 677 (1973), the high-water mark of the Supreme Court's willingness to disallow differential treatment of women and men. In striking down a rule that allowed male air force employees to claim wives as dependents, but forced female employees to meet special requirements to claim husbands as dependents, a plurality elevated women to suspect-class status. 
might believe that the relevant intent is the framers' "general" intent. ${ }^{76}$ These courts would be impressed by evidence of the framers' general awareness that the Fourteenth Amendment would be used in sex discrimination cases. They would consider irrelevant the framers' specific understanding of sexual equality: that is, the framers' view of which particular rights and responsibilities should be shared equally by women and men. For example, courts concerned with general intent would consider it crucial that in the 1870's Congress used the Fourteenth Amendment to determine the validity of the suffragists' claims. It would not much matter to these courts that the suffragists' petitions were ultimately denied. ${ }^{77}$

A court's willingness to rely on general intent would maximize the practical effect of the evidence presented in this Note. ${ }^{78}$ But even if this

76. This Note does not pretend to add to the lively debate over "general" intent. It merely argues that a court willing to rely on general intent might use the evidence presented in the Note to justify an expansion of the Fourteenth Amendment in sex discrimination cases. See infra note 78. For more on the general intent debate, compare R. DwORKIN, TAKING Rights SERIousLy 134-36 (1978) (distinguishing general "concepts" such as equality from particular "conceptions" of what constitutes equality in a given situation); and A. Bickel, The LEAST DANGerous Branch 102 (1962) (seeking specific answers to specific present-day problems is the wrong question to ask of historical materials relevant to the framing); and Amar, A Neofederalist View of Article III: Separating the Two Tiers of Federal Jurisdiction, 65 B.U.L. REv. 205, 258 n.169 (1985) (Fourteenth Amendment's open-ended language invites higher level of interpretive generality than Article III's precise language) with $R$. BERGER, supra note 70, at 13-19 ("generality" of equal protection guarantee is strictly circumscribed by framers' racial prejudice) and with Tushnet, Following the Rules Laid Down: A Critique of Interpretivism and Neutral Principles, 96 HARv. L. Rev. 781, 791-92 (1983) (no principled basis exists for choice of level of generality).

77. If courts were to rely on the framers' general intent, sex discrimination cases might be seen as analogous to racial discrimination cases involving desegregation or jury service. In desegregation cases, for example, courts are said to rely on the framers' general guarantee of racial equality, even though most of the framers were too bigoted to favor the particular remedy of desegregation. See Bickel, supra note 3, at 61-64. Similarly, courts could rely on evidence of the framers' general awareness that the Fourteenth Amendment would be used in sex discrimination cases. As in race cases, evidence of the framers' general willingness to allow sex discrimination claims would permit courts to replace the framers' specific understanding of what constitutes sexual equality with a more modern view.

This analogy between sex discrimination and racial discrimination is not perfect. Even if a court were concerned primarily with general intent, it still might find that framers' general intent toward women differed significantly from their general intent toward blacks. Congressmen spoke of blacks constantly during the framing and actively imagined how blacks might use the Amendment. With women, however, the evidence merely shows that many framers intended not to preclude women's use of the Amendment. Even a court willing to focus on general intent, then, might use a perceptible difference in the intensity of the framers' general intent to justify different levels of scrutiny in sex discrimination and racial discrimination cases.

One could, however, counter this argument by imagining an even higher level of interpretive generality on which the analogy between women and blacks would seem more exact. On this level of generality, the difference in intensity between the framers' intent toward women and their intent toward blacks would itself seem a matter of specific intent. As such, this difference in intensity could legitimately be ignored by modern courts that wished to pursue sexual and racial equality with the same degree of commitment. See infra note 78.

78. If courts were willing to rely on the framers' general intent, they might use this evidence to read the Fourteenth Amendment more expansively than they have done so far in sex discrimination cases. Today, sex discrimination claims are examined with an "intermediate" level of scrutiny. Courts require the government to justify sex-based classifications by showing that the classification is more than just a reasonable way to reach a legitimate goal. The government does not, however, have to show that the classification is a necessary way to reach a compelling goal, as it would under the more exacting "strict scrutiny" standard used in racial discrimination cases. See,e.g., Craig v. Boren, 429 U.S. 190 (1976). This intermediate level of scrutiny is used in part because women have not been able 
evidence falls short of proving the sort of intent that would influence a court's disposition of sex discrimination claims in the near future, it is valuable in a subtler way. The consensus view that the Fourteenth Amendment should reach sex discrimination is now thought to be supported only by the Amendment's language. ${ }^{79}$ If the framers' intent can plausibly provide additional support, then this view will stand even more firmly. As recently as last year, the consensus was challenged in public debate.$^{80}$ The claim that the framers' intent should preclude the use of the Fourteenth Amendment in sex discrimination cases could someday resurface; it could even begin to influence courts. The consensus view is only as sturdy as the arguments that support it. The evidence presented above reinforces the consensus view by suggesting that the Fourteenth Amendment's history, as well as its text, justifies the confident use of the Amendment in sex discrimination cases.

to Iay claim to the intent of the Fourteenth Amendment's framers. See generally Note, Sex Discrimination and Equal Protection: Do We Need a Constitutional Amendment?, 84 Harv. L. REv. 1499, 1509 (1971). If a court were to focus on general intent, it could use the evidence presented above to conclude that the Fourteenth Amendment's framers were willing to allow the amendment to reach sex discrimination. This conclusion, in turn, could help justify using strict scrutiny in sex discrimination cases.

79. See supra note 3 .

80. See supra note 2 . 